\title{
Compassion pada Pengasuhan Anak dengan Autism Spectrum Disorder
}

\section{Compassion in Parenting Children with Autism Spectrum Disorder}

\author{
Dinie Ratri Desiningrum ${ }^{1}$, Fendy Suhariadi ${ }^{2}$, Dewi Retno Suminar ${ }^{3}$ \\ 1,2,3Fakultas Psikologi, Universitas Airlangga \\ ${ }^{1}$ Fakultas Psikologi, Universitas Diponegoro
}

Submit 18 Mei 2019 Diterima 19 November 2019 Terbit 22 Juni 2020

\begin{abstract}
Compassion is defined as caring for the suffering of others and is followed up by helping. Various studies agree that compassion is important in human life, in various societal aspects. Compassion can stimulate the well-being of individuals and families. There are not many recent studies that examine compassion in the context of parenting, especially parenting of children with autism spectrum disorder even though compassion is part of the nurturing system that is manifested in providing love and protecting children. This literature study attempted to describe ontology and studies related to compassion, particularly compassion in parenting children with autism spectrum disorder. The aim was to understand compassion comprehensively and discover the concept of compassion in parenting children with autism spectrum disorder, so that it can be developed through further study which will benefit the community.
\end{abstract}

Keywords: autism spectrum disorder; compassion; ontology; parenting

Abstrak. Compassion adalah berbelas kasih terhadap penderitaan orang lain dan ditindaklanjuti dengan menolongnya. Compassion penting dalam kehidupan manusia, dan diterapkan di berbagai lapisan masyarakat. Dalam ranah keluarga, compassion dapat menstimulasi kesejahteraan individu dan keluarga. Penelitian terbaru belum banyak yang mengkaji compassion dalam konteks pengasuhan anak, khususnya anak dengan autism spectrum disorder. Tujuan dari studi hasil pemikiran ini adalah mencoba menggambarkan compassion, yaitu dalam hal ontologi dan penelitian-penelitian yang berkaitan dengan compassion khususnya compassion pada pengasuhan anak, dan lebih khusus lagi adalah compassion pada pengasuhan anak dengan autism spectrum disorder. Metode yang digunakan adalah studi literatur. Hasil studi ini menemukan pemahaman compassion secara komprehensif, dan menemukan konsep compassion dalam pengasuhan anak dengan autism spectrum disorder. Hasil penelitian bisa menjadi dasar konsep yang digunakan oleh peneliti lain yang berminat dalam ranah studi yang sama, yaitu untuk pengembangan studi lebih lanjut terkait pengasuhan anak berkebutuhan khusus, sehingga bisa bermanfaat bagi masyarakat.

Kata kunci: autism spectrum disorder; ontologi; compassion; pengasuhan

\footnotetext{
${ }^{1}$ Korespondensi mengenai artikel ini dapat melalui: dn.psiundip@gmail.com, fendy.suhariadi@psikologi.unair.ac.id, dewi.suminar@psikologi.unair.ac.id
} 


\section{Pengantar}

Orang tua dari anak berkebutuhan khusus, bisa mengalami stres pengasuhan yang berdampak pada kondisi psikologisnya. Orang tua atau caregiver dari anak dengan disabilitas perkembangan (seperti down syndrome atau cerebral palsy), dan autism spectrum disorder (ASD), banyak mengalami depresi, kecemasan, dan emotional distress (Da Paz, Wallander, \& Tiemensma, 2018). Faktor-faktor yang memengaruhi orang tua dan keluarga besar ketika merawat anak dengan keterbatasan, di antaranya adalah penyesuaian terhadap perilaku anak, kecukupan sumber daya yang dimiliki dan strategi koping yang adaptif, maka kegagalan dalam faktor tersebut bisa menyebabkan kondisi stressful (Cadwgan \& Goodwin, 2018) termasuk pada orang tua dari anakanak dengan down syndrome (Phillips, Conners, \& Curtner-Smith, 2017). Pada temuan riset lainnya dijelaskan bahwa parenting stress tinggi pada ibu dari anak dengan psychological disabilities dan neurodevelopmental disorders (NDDs), dan hal ini dipengaruhi oleh karakteristik psikologis ibu seperti kepuasan pernikahan, masalah-masalah emosional dan psikologis, tipe koping, serta level IQ (Frolli et al., 2016; Feizi et al., 2017).

Gangguan perkembangan anak yang bisa memicu stres bagi orang tua, salah satunya adalah autisme. Autisme adalah abnormalitas perkembangan dengan ciri utama yaitu gangguan pada kemampuan berkomunikasi dan bersosialisasi, serta terbatasnya dalam aktivitas dan ketertarikan. Gangguan ini bisa berkembang seiring dengan bertambahnya usia kronologis anak (Birch \& Bloom, 2004). Autisme pada dasarnya merupakan gangguan perkembangan otak, dengan gejala yang biasanya muncul sejak usia anak 2-3 tahun. Anak dengan autisme kurang mampu membangun dan mempertahankan komunikasi dengan lingkungan dan lemah dalam kontrol perilakunya (Desiningrum, 2016). Durig (Volkmar \& Pauls, 2003) menyatakan bahwa dalam logika atau cara anak dengan autisme berpikir dan berinteraksi sosial, terdapat ciri defisiensi dalam 'creative induction' yaitu dalam melakukan penalaran yang bersifat melihat hal-hal kecil sebagai bagian hal yang bersifat umum. Anak dengan autisme sering kali tidak memahami suatu kejadian dan hubungannya dengan kejadian lain.

Prevalensi autisme terus berkembang di berbagai belahan dunia, termasuk di Indonesia. Perkiraan jumlah penderita autisme adalah 1 dari 150 anak (67 dari 10.000) di Amerika Serikat (Garrecht \& Austin, 2011). Di Asia, prevalensi ASD adalah 14,8 / 10.000 penduduk (1980 2010). Di Cina prevalensi autisme adalah 10,3 / 10.000 penduduk (2000-2015) Sun, Allison, Auyeung, Baron-Cohen, \& Brayne, 2014), sedangkan di Jepang mencapai 27,2 / 10.000 penduduk (Ono \& Honda, 2017). Pada tahun 2013 di Indonesia terdapat sekitar 112.000 anak dengan autisme. Diperkirakan tahun 2020, ada sekitar 900.000 anak dengan autisme dan bisa terus bertambah jumlahnya (klinikautis.com, 2018). Di Palangkaraya, prevalensi autisme adalah satu per 250 penduduk (Lismaya, 2013).

Anak dengan ASD memiliki ciri perkembangan yang bisa menumbuhkan stres yang tinggi pada orang tua. Pengasuhan dan perawatan merupakan tugas yang secara alamiah melekat pada peran seorang ibu. Ibu atau orang tua yang memiliki anak dengan ASD, terus menghadapi tantangan dalam merawat anak dengan komitmen pengasuhan sepanjang hayat, dan ada suatu kekhawatiran terhadap masa depan anak ASD, 
sehingga ini berpotensi terhadap kesehatan mental ibu dan kualitas pengasuhan (Cohen \& Tsiouris, 2006; Delong, 2004; Hayes \& Watson, 2013; Huang et al., 2014; Da Paz et al., 2018; Walter \& Smith, 2016). Ibu dari anak dengan autisme rentan mengalami depresi. Dibutuhkan dukungan sosial, psikoedukasi dan treatment yang sesuai sedini mungkin; sehingga ibu bisa mengatur lebih baik kehidupan mereka dan perilakunya lebih adaptif sehingga berdampak positif pada relasinya dengan anak ASD (Das et al., 2017; Jose, Gupta, Gulati, \& Sapra, 2017). Stress yang tinggi pada ibu dari anak dengan autisme (Griffith et al., 2010), bisa mengganggu dalam menerapkan pengasuhan yang baik terhadap anak dimana ibu adalah pengasuh utama (Santrock, 2018).

Berdasarkan perspektif evolusi, dalam pengasuhan dan perawatan terhadap anak tercermin adanya compassion, yang berarti pula bahwa compassion merupakan bagian dari sistem pengasuhan yang terwujud dalam memberikan kasih sayang dan melindungi anak-anak (Gilbert, 2009; Goetz, Keltner, \& Simon-Thoma, 2010). Menurut Lazarus (1991), compassion adalah menunjukkan aksi terhadap orang lain yang mengalami penderitaan dan membutuhkan bantuan. Dalai Lama (1995) mengartikan compassion sebagai keterbukaan terhadap penderitaan orang lain dengan memunculkan komitmen dalam diri untuk membantunya. Feldman \& Kuyken, (2011) mengatakan bahwa compassion merupakan orientasi pikiran yang dapat memahami penderitaan dan pengalaman penderitaan orang lain dan kemampuan untuk mengatasi penderitaan tersebut dengan penuh kasih sayang, empati, kerelaan, dan kesabaran.

Banyak penelitian tentang compassion yang menunjukkan hasil positif, misalnya penelitian Sheldon \& Cooper (2008) yang menyatakan bahwa memelihara compassion dan menunjukkannya pada orang lain berkorelasi dengan kesejahteraan psikologis individu. Individu yang mengembangkan compassion terhadap orang lain merasakan mood yang positif (Hutcherson, Seppala, \& Gross, 2008). Suatu studi terhadap ibu dari anak dengan autisme menemukan bahwa compassionate parenting dapat memprediksi hasil positif untuk kepuasan pengasuhan, kepuasan hidup keluarga, makna hidup ibu dan efikasi pengasuhan ibu (Conti, 2015).

Compassion terkait dengan kesejahteraan individu, namun studi terkini meneliti compassion yang lebih ditekankan pada konteks pengasuhan, bahwa terdapat hubungan antara pengasuhan usia dini dan pembentukan compassion untuk usia selanjutnya. Karakteristik pengasuhan di usia dini berkontribusi pada pengembangan compassion dengan efek yang bertahan dalam kehidupan dewasa (Conti, 2015; Gluschkoff et al., 2018).

Compassion ibu terhadap anak autis ini sangat diperlukan, baik bagi ibu maupun tumbuh kembang anak. Ibu yang memiliki compassion akan menunjukkan adanya harapan positif dan goal re-engagement (tidak menuntut apa yang melebihi kemampuan) pada anak berkebutuhan khusus (Neff \& Faso, 2015). Banyak penelitian tentang manfaat dari compassion bagi individu yang memilikinya, namun belum ada penelitian di Indonesia khususnya yang mengkaji compassion ibu dalam pengasuhan dan perawatan terhadap anak autis. Maka dalam studi ini, penulis mencoba untuk menemukan konsep compassion dalam pengasuhan anak dengan autism spectrum disorder, dengan mengungkap dasar ilmu dari compassion secara umum, compassion dalam pengasuhan, serta menguraikan studi-studi mengenai compassion dalam pengasuhan, 
khususnya pengasuhan terhadap anak dengan autism spectrum disorder.

\section{Pembahasan}

Compassion menurut Webster Dictionary adalah "suatu kesadaran simpatik terhadap penderitaan yang dialami orang lain dan keinginan untuk meringankan penderitaannya." Sheryn Jimenez (2009) menjelaskan bahwa compassion adalah emosi pada individu ketika menanggapi penderitaan orang lain selanjutnya memotivasinya untuk menolong orang tersebut.

Dalam Bahasa Inggris compassion sebagai kata benda berarti "to love together with." Hal ini berasal dari Bahasa Latin "cum" (yang artinya "bersama") dan "passus" (dalam bentuk past participle dari kata kerja "pati", "passus sum", berarti "telah menderita"). Compassion memiliki kesamaan asal, bentuk dan makna dengan kata benda "patient" (orang yang menderita), dari Bahasa Latin yaitu "patiens", sebagai bentuk ketiga (past participle) dari kata kerja "patior" berarti "telah menderita", setara dengan kata kerja "paskhein" (Bahasa Yunani) berarti "menderita" dan kata benda "pathos" berarti "penyakit". Dapat disimpulkan bahwa Compassion mengandung arti "ikut dalam penderitaan orang lain yang sedang mengalami penderitaan" (Lama, 1995).

\section{Ontologi Compassion}

Ontologi merupakan suatu pemikiran tentang ada dan keberadaannya. Ontologi mempelajari tata dan struktur realitas seluas mungkin, dengan menggunakan konsep ada atau menjadi, esensi atau eksistensi, ruang, dan waktu (Suhartono, 2008). Sementara psikologi adalah ilmu yang mempelajari jiwa dan perilaku. Secara historis, pada awalnya psikologi adalah bagian dari filsafat (American
Psychological Association, 2018, dalam Hanurawan \& Suhariadi, 2019). Ontologi psikologi diantaranya mengkaji mengenai esensi dan eksistensi dari jiwa dan perilaku manusia (Hanurawan dan Suhariadi, 2019). Berikut pembahasan ontologi dari compassion.

Sikap berbelas kasih, yang kemudian dikembangkan menjadi istilah compassion mulai tergelitik untuk diteliti sebelum Perang Dunia II, sosiolog Charles Cooley pada tahun 1912 (Roeser \& Eccles, 2015) mengeluarkan suatu teori hasil penelitian self dan sosial. Beliau memperkenalkan konsep "cermin diri". Artinya, pembentukan self sangat bergantung pada respons orang-orang di sekitar, dan perlakuan orang-orang tersebut terhadap individu, seperti melihat ke cermin. Konsep self ini terinspirasi kemudian dikembangkan dari buku klasik "Cermin Lewis Carroll" (Hansen, 2001). Harry Stack Sullivan (1953) juga menekankan efek umpan balik yang dirasakan dari orang lain terhadap diri. Individu bisa merasa penting tergantung dari orang lain menanggapi dan bereaksi terhadap dirinya, maka penilaian mattering atau seberapa penting dirinya, bisa memanfaatkan refleksi tersebut (Flett, 2018).

Lahirnya compassion diawali dengan adanya interaksi antara self dan lingkungan. Teori eksistensialisme mengkaji mengenai self, dalam kaitannya dengan interaksi sosial. Eksistensialisme secara historis muncul pada awal abad ke sembilan belas, meskipun masih dalam bentuk embrional. Usai perang dunia, filsafat ini berkembang pesat dan berpengaruh kuat di Eropa dan Amerika. Filsafat ini memandang manusia dalam arti eksistensi, bukan esensi. Penekanan bahwa eksistensi adalah yang terpenting (Sartre, 1948). Eksistensi asal katanya adalah "eks" yang artinya "keluar" dan "sistensi" berarti "berdiri, 
menempatkan". Eksistensi adalah manusia itu berdiri sebagai diri sendiri yang memiliki kesadaran bahwa dirinya ada. Ketika berada diluar maka manusia akan sadar bahwa dirinya ada dan memiliki kebebasan. Eksistensi adalah suatu keadaan aktual diri dalam ruang dan waktu, terdapat kehidupan "self" yang berfungsi penuh, dengan kesadaran, penuh tanggung jawab dan bisa bertransformasi (Collins, 1952).

Sosiolog George Herbert Mead, (1934) mengeksplorasi tema serupa, yaitu tentang "self", dalam teori interaksionisme simbolisnya. Inti dari teori ini adalah bahwa seseorang datang untuk melihat diri dari sudut pandang kelompok sosial. Refleksi diri adalah konstruksi sosial yang melibatkan peran yang orang lain harapkan untuk diadopsi melalui kehadiran mereka. Interaksionisme simbolis melibatkan treatment yang diterima dari orang lain, persepsi individu tentang treatment ini, dan bagaimana umpan baliknya membentuk konsep-diri individu. Mead menyebutkan bahwa "self" muncul dan dikembangkan melalui pengalaman sosial orang lain; tidak ada diri atau definisi diri tanpa orang lain. Penelitiannya pada sosok anak, menemukan bahwa ada alasannya untuk percaya bahwa anak juga mampu bercermin, untuk menghayati perasaan dirinya, memahami keadaan emosional dari orang tua, terdapat proses identifikasi terhadap orang tua yang kemudian berlanjut ke dalam domain perasaan diri, termasuk perasaan kasih sayang atau compassion.

Lebih lanjut lagi, terdapat suatu teori konstruksi personal oleh George A. Kelly tahun 1948 (Chiari, 2017), yang menyebutkan bahwa perilaku manusia selain dipengaruhi oleh lingkungannya, juga dibentuk oleh pikirannya. Compassion intinya adalah self, yaitu menjadi manusia
(Blum, 1988 dalam Schwartz et al., 2018; Feldman \& Kuyken, 2011). Persepsi individu tentang realitas dipengaruhi oleh konstruk personalnya-atau bagaimana cara individu melihat, menerangkan dan menginterpretasi kejadian di dunianya. Kepribadian individu merupakan kumpulan konstruk personal yang digunakan individu untuk menginterpretasi dunia. Konstruk personal pada manusia berisi pengalaman dan pengetahuan tentang dunia hasil proses kognitif dalam kategorisasi, atribusi, prediksi dan interpretasi pada setiap wujud dan peristiwa yang ada di lingkungannya. Dengan konstruk personal ini maka manusia bebas dalam memutuskan dan membatasi tindakannya, karena manusia akan berhadapan dengan makna peristiwa, dirinya tidak akan pernah bisa memutuskan hal-hal terkait di luar dunianya (Burr, Giliberto, \& Butt, 2014; Flett, 2018).

Penelitian-penelitian psikologi dengan pendekatan filsafat konstruktivisme mencoba melakukan pemahaman terhadap konteks sosial psikologis dan cara partisipan memberi makna terhadap konteks sosial tersebut (Dalton et al., dalam Hanurawan \& Suhariadi, 2019). Pada seorang ibu atau caregiver anak, akan terbentuk konstruk personal sebagai pengasuh dari anak dengan kekhasan sifat dan perilaku anak (Mash \& Wolfe, 2013), ada kalanya individu mengalami stres terlebih lagi pada caregiver dari anak dengan autism spectrum disorder (Hayes \& Watson, 2013). Pada ibu yang compassion terkonstruksi self yang unik, ibu cenderung percaya bahwa dirinya adalah ibu yang istimewa, karena harus mampu melalui berbagai tantangan merawat anaknya, dan mengembangkan ikatan yang hangat dengan anak.

Sebuah konstruk personal yang terbentuk akan berguna bagi manusia untuk 
memprediksi peristiwa yang bisa terjadi di masa depan. Hal ini bisa terjadi karena konstruk personal merupakan kumpulan pengalaman dan pengetahuan tentang dunianya. Terdapat suatu metafora yaitu "orang sebagai ilmuwan" (person as scientist). Individu dapat mengembangkan ide yang memungkinkan dirinya memprediksi peristiwa penting di kehidupan sehari-hari (Kelly, 1969 dalam Chiari, 2017). Maka demikian pula yang terjadi pada konstruk personal seorang ibu ataupun caregiver dari anak dengan autisme, ibu/caregiver dengan compassion akan merasa bahwa dirinya adalah orang yang paling tahu tentang keadaan anaknya, bagaimana menstimulasi perkembangan anak, terus mengembangkan diri untuk meningkatkan kemampuan pengasuhan anak, dan bisa memprediksi perilaku anak yang muncul dan tumbuh kembang anak selanjutnya (Conti, 2015; Lovell \& Wetherell, 2015).

Menurut Kelly (Kelly, 1969 dalam Chiari, 2017), manusia secara berkesinambungan membentuk pandangan mereka tentang dunianya (dinamis). Pada diri setiap manusia memiliki core construct (konstruk inti) sebagai fungsi dasar dan tidak akan bisa diubah kecuali dengan konsekuensi besar pada sistem konstruk yang ada; dan memiliki peripheral construct (konstruk pelengkap) yaitu konstruk penunjang yang dapat diubah sesuai kebutuhannya. Pada caregiver dari seorang anak dengan autisme, maka konstruk personal dapat terus menerus terbentuk dan bersifat dinamis, bahwa caregiver mampu menyertai anaknya yang semakin dewasa dan menunjukkan progres, baik dalam tumbuh kembangnya, caregiver dengan compassion akan menghargai perkembangan anak dengan ASD sekecil apa pun (Murphy, Burns, \& Kilbey, 2017).
Compassion lebih kompleks dari emosi lainnya. Yaitu menuntut pengetahuan diri tentang penderitaan orang lain dan menggerakkan untuk bertindak (Batson, Ahmad, Lishner, \& Tsan, 2002). Compassion membantu seseorang lebih mengetahui bahwa orang lain menderita, bisa mengidentifikasi diri dengan penderitanya, memiliki pengetahuan mengenai apa saja yang dialami penderitanya. Hal ini tentu saja sangat dibutuhkan pada pengasuhan anak dengan autisme. Seorang ibu senantiasa merawat dan membantu anak dalam kehidupan seharihari, tanpa mengharap balasan tentunya, terlebih pada ibu dari anak dengan ASD, di mana karakter anak dengan autisme yang umumnya memiliki keterbatasan dalam berkomunikasi, dangkal dalam empati, dan mudah tantrum (Desiningrum, 2019).

Compassion sering kali diidentikkan dengan kasih sayang (Gilbert, 2009). Kasih sayang adalah emosi sepihak, belum menentukan untuk membangkitkan perasaan yang sama dalam diri orang lain. Kasih sayang yang menjadi bagian dari compassion tetap bisa dirasakan, dimana penderitaan orang lain dapat membawa kesedihan bagi individu dengan compassion, meskipun tidak dekat dalam ruang dan waktu. Di sisi lain, kasih sayang juga disebut sebagai salah satu ekspresi kebahagiaan terhadap orang lain, dan kepekaan untuk penderitaan orang lain (Feldman \& Kuyken, 2011). Semakin banyak individu tahu tentang orang lain, maka akan semakin sedikit individu tersebut menyalahkan orang lain itu untuk kemalangan yang mereka alami. Kedua prinsip kasih sayang ini yang juga menjadi bagian dari compassion, tepat dalam mengkaji pengasuhan anak dengan autisme. Seorang ibu mampu memahami kebutuhan dan merasakan keadaan emosional 
anaknya, tanpa banyak bercakap-cakap. Ketika anak mengalami kesedihan atau penderitaan yang sukar untuk dipahami penyebabnya, maka bagi ibu tidak sulit untuk tetap menuangkan perhatian dan bantuan. Beberapa ciri anak dengan ASD yaitu ketidakmampuan dalam prinsip executive function, khususnya dalam regulasi emosi; serta keterbatasan dalam theory of mind, yaitu kemampuan 'membaca' pikiran orang lain (Desiningrum, 2019), keseluruhannya dapat menjadikan beban pengasuhan yang lebih besar pada caregiver dari anak dengan ASD. Dengan compassion, maka ibu bisa terhindar dari stres berkepanjangan (Das et al., 2017).

Istilah compassion mengesankan adanya paralelisme makna dengan empati dan simpati (Darwall, 1998; Gilbert et al., 2017). Pada dasarnya seluruh konstruk memiliki perbedaan mendasar. Empati dan simpati merupakan dua konstruk yang sama-sama menggambarkan sifat peduli pada orang lain yaitu individu mampu menempatkan diri dan ikut merasakan penderitaan dari orang lain (perilaku altruistik). Kedua konstruk mencerminkan tindakan menolong meringankan hingga membebaskan penderitaan orang lain, namun penekanannya berbeda. Simpati mengandung pengertian ikut menderita bersama orang lain dan adanya keinginan untuk meringankan penderitaan orang lain. Pada empati, berupa sikap ikut merasakan penderitaan orang lain namun bukan untuk kepentingan korban, melainkan diri sendiri (Chierchia \& Singer, 2016; Darwall, 1998). Adanya perasaan ikut menderita ketika orang lain mengalami penderitaan bisa terjadi karena individu sedang mengalami situasi penderitaan yang sejenis, maka ia bisa merasakan kedalaman penderitaan, sehingga ketakutan sesuatu menimpa korban pada dasarnya merupakan kekha- watiran terhadap diri yang ia proyeksikan (Darwall, 1998).

Compassion lebih tercermin dalam konstruk simpati, bukan empati. Pernyataan Mencius (Darwall, 1998) yaitu: "Suppose a man were, all of a sudden, to see a young child on the verge of falling into a well. He would certainly be moved to compassion". Compassion merupakan keinginan menolong dan membebaskan penderitaan orang lain dengan melihat kepentingan korban/ penderita, bukan untuk diri sendiri. Compassion diawali dengan perasaan yang muncul ketika mengetahui penderitaan orang lain, ada belas kasihan sehingga mendorong untuk “...berusaha sekuat tenaga dalam menghapus penderitaan orang lain, mengistirahatkan diri dari perhatian dan energi kita serta menempatkan orang yang menderita untuk diperhatikan yang diwarnai oleh rasa hormat akan kesucian setiap manusia, maka selanjutnya akan memperlakukan setiap orang, siapapun itu, dengan adil, setara, dan sikap menghormati" (Armstrong, 2012).

Simpati dan compassion sama-sama bertitik tolak dari kepentingan penderita, tetapi keduanya berbeda dalam komponen motivasional dan kedalaman (depth). Individu bisa bersikap simpati terhadap penderitaan orang lain tetapi dirinya bisa menentukan untuk tidak menolong orang tersebut. Sebaliknya, sikap compassion terhadap penderitaan orang lain hampir selalu disertai komitmen untuk menolongnya. "To be compassionate is to be moved in a certain way; it is to be motivated to act for the benefit of the other as one might act for oneself in a similar situation" (Churchill \& Street, 2005). Dibutuhkan ibu yang compassion pada anak dengan autism spectrum disorder yaitu ibu yang bersedia menolong dan memberikan kasih sayang tanpa syarat terhadap anak, sehingga anak bisa aman 
dan merasakan nyaman dalam tumbuh kembangnya di tengah berbagai keterbatasan.

\section{Studi-studi Compassion}

Sebagai sebuah ilmu, psikologi memiliki tujuan-tujuan yang ingin dicapai, yaitu mendeskripsikan, menjelaskan, meramal, mengendalikan dan memecahkan masalah (Hanurawan \& Suhariadi, 2019). Studistudi mengenai compassion terus dikembangkan dengan berdasar pada tujuantujuan tersebut.

Neff (2003) melakukan studi mengenai compassion. Compassion menurut Neff (2003) adalah baik dan pengertian terhadap orang yang sedang mengalami penderitaan atau kegagalan, bukan bersikap kritis; teori ini mempersepsikan pengalaman seseorang sebagai bagian dari pengalaman manusia yang lebih besar, bukan sebagai individu yang terisolasi; dan memahami bahwa terdapat pikiran dan perasaan yang sedang sakit bukan mengidentifikasinya. Compassion secara signifikan berkorelasi dengan kesehatan mental yang positif seperti rendahnya depresi dan kecemasan serta tingginya kepuasan hidup.

Model self-compassion menurut Neff \& Faso, (2015), menggambarkan tentang orang tua dari anak-anak dengan autisme yang selalu dihadapkan dengan stressor harian yang menyulitkan dan unik, terkait gangguan pada anak. Karakteristik pribadi orang tua bisa memengaruhi bagaimana mereka menghadapi stres dan berpotensi membantu mereka mengatasi beberapa efek yang merusak dikaitkan dengan stres yang ekstrem. Self compassion ditemukan sebagai salah satu faktor yang menjadi strategi penanggulangan yang penting, yang merupakan sikap baik kepada diri sendiri pada saat mengalami kesulitan, sharing penderitaan dengan sesama atau ahli, dan memiliki kesadaran kognitif dan mengontrol emosi negatif. Hasil penelitian menyebutkan bahwa self-compassion berhubungan positif dengan kepuasan hidup, harapan, dan goal re-engagement dan berhubungan negatif dengan depresi serta stres orang tua. Self compassion dapat berperan penting dalam pembentukan kesejahteraan orang tua dari anak-anak autisme.

Compassion menurut Gilbert (2009) mengandung enam atribut, yaitu: sensitivitas, simpati, empati, motivasi, toleransi terhadap distres, dan non-judgement. Sensitivitas yang dimaksud adalah responsif terhadap kondisi emosi dan kebutuhan anak. Simpati diartikan memperlihatkan perhatian terhadap penderitaan yang dialami anak, sedangkan empati diartikan sebagai menempatkan perasaan orang lain pada diri sendiri. Motivasi yang dimaksudkan adalah adanya dorongan untuk bertindak dalam memberikan kasih sayang terhadap anak. Toleransi terhadap distres didefinisikan sebagai kemampuan menoleransi emosi-emosi sulit yang muncul dalam diri saat kesulitan menghadapi kondisi orang lain (anak) tanpa terpengaruh oleh kondisi-kondisi tersebut. Toleransi terhadap distres ini sangat penting, saat caregiver merasakan distres personal yang kuat dalam pengasuhan anak dengan autisme, caregiver tidak akan terlalu fokus pada ketidaknyamanan dalam dirinya yang dapat menghambat kemampuannya dalam memberikan pengasuhan dan perawatan. Atribut compassion yang terakhir adalah nonjudgement yang didefinisikan sebagai kemampuan untuk menerima dan toleran terhadap kondisi apa pun yang dialami anak.

Dari hasil suatu studi literatur, ditemukan bahwa compassion terdiri dari lima elemen, yaitu mengenal suatu pende- 
ritaan; memahami bahwa penderitaan manusia bersifat universal; adanya perasaan simpati, empati atau perhatian terhadap orang yang menderita (resonansi emosional); menoleransi distres ketika menyaksikan penderitaan; dan motivasi untuk bertindak/bertindak untuk mengurangi penderitaan (Strauss et al., 2016).

Model lain mengenai compassionate parenting menurut Conti (2015), menyebutkan bahwa compassionate parenting dapat memprediksi hasil positif untuk kepuasan pengasuhan, kepuasan hidup keluarga, makna hidup ibu dan efikasi pengasuhan ibu dari anak dengan autisme (Conti, 2015). Dilakukan dua studi, hasilnya adalah compassionate parenting memprediksi hasil positif yaitu untuk kepuasan pengasuhan (kedua studi), kepuasan hidup keluarga, makna hidup (Studi 1) dan efikasi pengasuhan (Studi 2). Studi-studi ini mendukung gagasan bahwa compassionate parenting adalah kunci untuk kepuasan bagi ibu dari anakanak dengan autisme.

Studi lain dilakukan oleh Aydin (2015), yang mengukur skor self-compassion pada ayah-ibu dari anak dengan disabilitas mental dan autistic, dan diungkapkan bahwa subdimensi over-identification dari skala self-compassion tergolong negatif. Artinya, ketika orang tua memiliki anak dengan disabilitas, maka terbentuk sikap mengidentifikasi secara berlebihan pada diri orang tua, dan hal ini dapat memengaruhi orang tua dalam memberikan pengasuhan.

Dalam studi lain, ditemukan sebuah model compassionate love di masa anak usia dini yang mengambil model dasar Compassionate Love yang dirumuskan oleh Underwood (2002), menjelaskan lebih lanjut bentuk perilaku prososial anakanak, emosi, dan pemahaman kognitif. Perilaku prososial (yaitu, membantu, berbagi, menghibur) mencerminkan compassionate love yang diungkapkan oleh anak usia dini. Di dalamnya terdapat motivasi atau proses internal yang bertanggung jawab atas perilaku yang diekspresikan, termasuk emosi moral dari rasa bersalah dan empati, serta proses kognitif dalam pemahaman diri dan perspektif afektif. Anak-anak yang mengalami simpati akan mencoba untuk mengurangi penderitaan orang lain, sedangkan anak-anak yang mengalami personal distress akan mencoba untuk menghindari situasi yang menyedihkan atau menanggapi secara agresif (Volling, Kolak, \& Kennedy, 2009).

Studi-studi compassion seperti yang dipaparkan di atas, menunjukkan pentingnya compassion pada individu, termasuk dalam pengasuhan anak dengan autism spectrum disorder. Dapat disimpulkan melalui studi-studi terdahulu, bahwa compassion pada ibu dari anak dengan ASD merupakan sikap ibu dalam mengasuh anak dengan autisme, yang mencakup kognisi, afeksi dan konasi, dengan kesadaran terdalam akan kesulitankesulitan atau penderitaan yang dialami anak, yang disertai usaha untuk membantu meringankan/mengatasi kesulitan yang dialami anak.

Studi selanjutnya dapat fokus pada menggali lebih banyak tentang faktorfaktor yang menjadi determinan dari compassion, agar pengetahuan mengenai compassion dapat lebih berkembang dan komprehensif, sehingga bermanfaat untuk masyarakat khususnya dalam pengasuhan anak dengan autism spectrum disorder.

\section{Penutup}

Compassion diartikan sebagai perasaan individu yang muncul sebagai tanggapan terhadap penderitaan orang lain yang 
kemudian memotivasi dan mendorongnya untuk menolong. Compassion diperlukan bagi individu yaitu dalam berinteraksi secara harmonis dengan lingkungannya, termasuk dalam memberikan pengasuhan terhadap anak. Studi ini menemukan konsep compassion dalam pengasuhan anak dengan autism spectrum disorder. Compassion pada ibu dari anak dengan ASD merupakan sikap ibu dalam mengasuh anak dengan ASD yang mencakup kognisi, afeksi dan konasi, dengan kesadaran terdalam akan kesulitan-kesulitan atau penderitaan anak, yang disertai usaha untuk membantu meringankan/mengatasi kesulitan yang dialami anak.

Implikasi dari temuan tulisan ini adalah konsep compassion pada ibu dari anak dengan ASD, sesuai dengan masyarakat Indonesia, dengan sifat khas budaya timurnya mengenai sikap simpati, empati, dan prososial (Sumantri \& Suharnomo, 2011), yang menjadi bagian dari konsep compassion (Volling et al., 2009).

Selain dikenal sebagai masyarakat yang heterogen, Indonesia juga merupakan salah satu negara yang memiliki kebudayaan yang bersifat kolektivis (Hofstede, Hofstede, \& Minkov, 2010). Hasil penemuan suatu studi (Sumantri \& Suharnomo, 2011) di Indonesia, ditemukan bahwa dalam dimensi maskulinitas yang sedang, ibu tetap memainkan peran yang tinggi terhadap pengasuhan anak. Maka sikap dan pengetahuan ibu mengenai anak autisnya menjadi hal yang penting (Meirsschaut, Roeyers, \& Warreyn, 2010; Ortner, Müller, \& GarciaRetamero, 2011) dan compassion ibu dalam mengasuh anak dengan ASD menjadi sesuai dalam kultur Indonesia.

Pentingnya compassion dan penemuan konsep compassion dalam pengasuhan anak dengan ASD ini selanjutnya dapat dikembangkan oleh peneliti lain yang tertarik dengan bidang keluarga atau pengasuhan anak berkebutuhan khusus, misalnya dengan mengembangkan modelmodel intervensi terkait konsep compassion.

\section{Daftar Pustaka}

Armstrong, K. (2012). Compassion: 12 langkah menuju hidup berbelas kasih. Bandung: Mizan.

Aydin, A. (2015). A comparison of the alexithymia, self-compassion and humour characteristics of the parents with mentally disabled and autistic children. Procedia - Social and Behavioral Sciences, 174, 720-729. doi: 10.1016/j.sbspro.2015.01.607

Batson, C. D., Ahmad, N., Lishner, D. A., \& Tsang, J. A. (2002). Empathy and altruism. In Handbook of positive psychology (C. R. Snyd, pp. 485-498). New York: Oxford University Press.

Birch, S. A. J., \& Bloom, P. (2004). Understanding children's and adults' limitations in mental state reasoning. Trends in Cognitive Sciences, 8(6), 255260. doi: $10.1016 / j . t i c s .2004 .04 .011$

Burr, V., Giliberto, M., \& Butt, T. (2014). Construing the cultural other and the self: A Personal construct analysis of English and Italian perceptions of national character. International Journal of Intercultural Relations, 39(1), 53-65.

doi: 10.1016/j.ijintrel.2013.09.012

Cadwgan, J., \& Goodwin, J. (2018). Helping parents with the diagnosis of disability. Paediatrics and Child Health, 28(8), 357-363. doi: 10.1016/j.paed.2018.06.006

Chiari, G. (2017). George A . Kelly and his personal construct theory. Diakses dari : 
https://www.researchgate.net/publica tion/317064022 George A Kelly and His_Personal Construct Theory iBo ok

Chierchia, G., \& Singer, T. (2016). The neuroscience of compassion and empathy and their link to prosocial motivation and behavior. In J.-C. Dreher \& L. Tremblay (Eds.), Decision Neuroscience: An Integrative Perspective (pp. 247-257). Cambridge, MA: Academic Press. doi: 10.1016/B978-0$\underline{12-805308-9.00020-8}$

Churchill, R. P., \& Street, E. (2005). Is there a paradox of altruism. The ethics of altruism. London: Frank Cass Publisher.

Cohen, I. L., \& Tsiouris, J. A. (2006). Maternal recurrent mood disorders and high-functioning autism. Journal of Autism and Developmental Disorders, 36(8), 1077-1088. doi: 10.1007/s10803$\underline{006-0145-7}$

Collins, J. (1952). The existentialists: A critical study. Chicago: H. Regnery Co.

Conti, R. (2015). Compassionate parenting as a key to satisfaction, efficacy and meaning among mothers of children with autism. Journal of Autism and Developmental Disorders, 45(7), 20082018. doi: $\underline{10.1007 / s 10803-015-2360-6}$

Da Paz, N. S., Wallander, J. L., \& Tiemensma, J. (2018). Effects of written disclosure on psychophysiological stress among parents of children with autism: A randomized controlled pilot study. Research in Autism Spectrum Disorders, 53(June), 7-17. doi: 10.1016/j.rasd.2018.05.007

Darwall, S. (1998). Empathy, sympathy, care. Philosophical Studies, 6(5), 420423. doi: 10.1023/A:1004289113917

Das, S., Das, B., Arunima, D., Kakoli, N.,
Bora, P., \& Hazarika, M. (2017). Impact of stress, coping, social support, and resilience of families having children with autism: A North East India-based study. Asian Journal of Psychiatry, 28, 133-139. doi: 10.1016/j.ajp.2017.03.040

Delong, R. (2004). Neuropsychiatrc practice and opinions, autism and familial major mood disorder: Are they related? Journal of Neuropsychiatry and Clinical Neurosciences, 16(16), 199-213.

Desiningrum, D. R. (2016). Psikologi anak berkebutuhan khusus. (G. Ilmu, Ed.) (Edisi pertama). Yogyakarta: Psikosains.

Desiningrum, D. R. (2019). Memahami anak dengan gangguan spektrum autisme. In Bunga Rampai Psikologi Perkembangan: Memahami Dinamika Perkembangan Anak (pp. 111-130). Sidoarjo: Zifatama Jawara.

Feizi, A., Hovsepian, S., Azhar, S. M. M., Najmi, B., Momeni, F., \& Heidari, Z. (2017). Do psychological characteristics of mothers predict parenting stress? A cross-sectional study among mothers of children with different disabilities. Archives of Psychiatric Nursing, 32(3), 396-402. doi: 10.1016/j.apnu.2017.12.004

Feldman, C., \& Kuyken, W. (2011). Compassion in the landscape of suffering. Contemporary Buddhism, 12(1), 143-155. doi: $\underline{10.1080 / 14639947.2011 .564831}$

Flett, G. L. (2018). Mattering as a psychological construct. In G. L. Flett (Ed.), The Psychology of Mattering: Understanding the Human Need to be Significant (pp. 51-74). doi: 10.1016/B978-0-12-809415-0.00004-9

Frolli, A., Conson, M., Margari, L., 


\section{DESININGRUM, DKK}

Margari, F., Monaco, M., Craig, F., ... Ivagnes, S. (2016). Parenting stress among parents of children with Neurodevelopmental Disorders. Psychiatry Research, 242, 121-129. doi: 10.1016/j.psychres.2016.05.016

Garrecht, M., \& Austin, D. W. (2011). The plausibility of a role for mercury in the etiology of autism: A cellular perspective. Toxicological and Environmental Chemistry, 93(6), 12511273. doi:

10.1080/02772248.2011.580588

Gilbert, P. (2009). An Introduction to compassion focused therapy. Advances in Psychiatric Treatment, 15(2), 199-208. doi:

10.1521/ijct.2010.3.2.97

Gilbert, P., Catarino, F., Duarte, C., Matos, M., Kolts, R., Stubbs, J., ... Basran, J. (2017). The development of compassionate engagement and action scales for self and others. Journal of Compassionate Health Care, 4(1), 1-25. doi: 10.1186/s40639-0170033-3

Gluschkoff, K., Oksman, E., Knafo-Noam, A., Dobewall, H., Hintsa, T., Keltikangas-Järvinen, L., \& Hintsanen, M. (2018). The early roots of compassion: From child care arrangements to dispositional compassion in adulthood. Personality and Individual Differences, 129(March), 28-32. doi: 10.1016/j.paid.2018.03.005

Goetz, J. L., Keltner, D., \& Simon-Thomas, E. (2010). Compassion: An evolutionary analysis and empirical review. Psychological Bulletin, 136(3), 351-374. doi: 10.1037/a0018807

Griffith, G. M., Hastings, R. P., Nash, S., \& Hill, C. (2010). Using matched groups to explore child behavior problems and maternal well-being in children with down syndrome and autism. Journal of Autism and Developmental Disorders, 40(5), 610-619. doi: 10.1007/s10803-009-0906-1

Hansen, J. (2001). Reconstructing Lewis Carroll's Looking Glass. Iowa Journal of Cultural Studies, 01(20), 1-18. doi: 10.17077/2168-569x.1346

Hanurawan, F., \& Suhariadi, F. (2019). Filsafat ilmu psikologi. Bandung, Indonesia: PT Remaja Rosdakarya.

Hayes, S. A., \& Watson, S. L. (2013). The impact of parenting stress: A metaanalysis of studies comparing the experience of parenting stress in parents of children with and without autism spectrum disorder. Journal of Autism and Developmental Disorders, 43(3), 629-642. doi: 10.1007/s10803012-1604-y

Huang, C. Y., Yen, H. C., Tseng, M. H., Tung, L. C., Chen, Y. D., \& Chen, K. L. (2014). Impacts of autistic behaviors, emotional and behavioral problems on parenting stress in caregivers of children with autism. Journal of Autism and Developmental Disorders, 44(6), 1383-1390. doi: 10.1007/s10803-013-2000-y

Hutcherson, C. A., Seppala, E. M., \& Gross, J. J. (2008). Loving-kindness meditation increases social connectedness. Emotion, 8, 720-724.

Jimenez, S. (2009). Compassion. In The encyclopedia of positive psychology (Shane Lope). New Jersey: WileyBlackwell.

Jose, A., Gupta, S., Gulati, S., \& Sapra, S. (2017). Prevalence of depression in mothers of children having ASD. Current Medicine Research and Practice, 7(1), 11-15. doi: 10.1016/j.cmrp.2016.12.003

klinikautis.com. (2018). Angka kejadian autis 
di Indonesia dan di berbagai belahan dunia lainnya. Diakses dari: https://klinikautis.com/2018/03/24/an gka-kejadian-autis-di-indonesia-dandi-berbagai-belahan-dunia-lainnya/

Lama, D. (1995). The power of compassion. New York: HarperCollins Publisher.

Lazarus, R. S. (1991). Emotion and adaptation. Oxford: Oxford University Press.

Lismaya. (2013). Penanggulangan autisme. Menyongsong hari autis sedunia. Diakses dari: http://www.melaticeria.or.id/2013/04/ penanggulangan-autisme.html

Lovell, B., \& Wetherell, M. A. (2015). Child behaviour problems mediate the association between coping and perceived stress in caregivers of children with autism. Research in Autism Spectrum Disorders, 20, 17-23. doi: $\underline{10.1016 / j . r a s d .2015 .08 .003}$

Mash, J. E., \& Wolfe, D. (2013). Abnormal child psychology. Belmont, CA: Wadsworth Cengage Learning.

Mead, G. H. (1934). Mind, self, and society: From the standpoint of a social behaviorist. Chicago: University of Chicago Press.

Meirsschaut, M., Roeyers, H., \& Warreyn, P. (2010). Parenting in families with a child with autism spectrum disorder and a typically developing child: Mothers' experiences and cognitions. Research in Autism Spectrum Disorders, 4(4), 661-669. doi: 10.1016/j.rasd.2010.01.002

Murphy, M., Burns, J., \& Kilbey, E. (2017). Using personal construct methodology to explore relationships with adolescents with Autism Spectrum Disorder. Research in Developmental Disabilities, 70(August 2016), 22-32. doi:

\subsection{6/j.ridd.2017.08.006}

Neff, K. D. (2003). The development of a scale to measure self-compassion. Self and Identity, 2, 223-250.

Neff, K. D., \& Faso, D. J. (2015). Selfcompassion and well-being in parents of children with autism. Mindfulness, 6(4), 938-947. doi: 10.1007/s12671-014$\underline{0359-2}$

Ono, M., \& Honda, S. (2017). Association between social support and child abuse potential among Japanese mothers. Children and Youth Services Review, 73, 88-92. doi: $\underline{10.1016 / j . c h i l d y o u t h .2016 .12 .003}$

Ortner, T. M., Müller, S. M., \& GarciaRetamero, R. (2011). Estimations of parental and self intelligence as a function of parents' status: A crosscultural study in Germany and Spain. Social Science Research, 40(4), 10671077.

doi:

10.1016/i.ssresearch.2011.03.006

Phillips, B. A., Conners, F., \& CurtnerSmith, M. E. (2017). Parenting children with down syndrome: An analysis of parenting styles, parenting dimensions, and parental stress. Research in Developmental Disabilities, 68(July), 9-19. doi: 10.1016/j.ridd.2017.06.010

Roeser, R. W., \& Eccles, J. S. (2015). Mindfulness and compassion in human development: introduction to the special section. Developmental Psychology, 51, 1-6. doi: $\underline{10.1037 / \mathrm{a} 0038453}$

Santrock, J. W. (2018). A topical approach to life-span development (Edisi kesembilan). New York: McGrawHill.

Sartre, J.-P. (1948). Existentialism $\mathcal{E}$ humanism. London: Methuen. 
Schwartz, J., Huntington, N., Toomey, M., Laverdiere, M., Bevans, K., Blum, N., \& Bridgemohan, C. (2018). Measuring the involvement in family life of children with autism spectrum disorder: A DBPNet study. Research in Developmental Disabilities, 83(July 2017), 18-27. doi:

10.1016/j.ridd.2018.07.012

Sheldon, K. M., \& Cooper, M. L. (2008). Goal striving within agentic and communal roles: Separate but functionally similar pathways to enhanced well-being. Journal of Personality, 76, 415-447.

Strauss, C., Taylor, B. L., Gu, J., Kuyken, W., Baer, R., Jones, F., \& Cavanagh, K. (2016). What is compassion and how can we measure it? A review of definitions and measures. Clinical Psychology Review, 47, 15-27. doi: 10.1016/j.cpr.2016.05.004

Suhartono, S. (2008). Filsafat pendidikan. Yogyakarta: Ar-Ruzz Media.

Sullivan, H. S. (1953). The interpersonal theory of psychiatry. New York: W W Norton \& Co.

Sumantri, S., \& Suharnomo. (2011). Kajian proposisi hubungan antara dimensi budaya nasional dengan motivasi dalam suatu organisasi usaha. Pustaka Unpad. http://pustaka.unpad.ac.id/wpcontent/uploads/2011/04/kajian prop osisi hub antara dimensi budaya $\mathrm{n}$ asional.pdf

Sun, X., Allison, C., Auyeung, B., BaronCohen, S., \& Brayne, C. (2014). Parental concerns, socioeconomic status, and the risk of autism spectrum conditions in a populationbased study. Research in Developmental Disabilities, 35(12), 3678-3688. doi: 10.1016/j.ridd.2014.07.037

Underwood, L. G. (2002). The human experience of love: Conceptual mapping and data from selected studies. In Altruism and altruistic love: Science, philosophy, and religion in dialogue (S. G. Post, pp. 72-88). New York: Oxford University Press.

Volkmar, F. R., \& Pauls, D. (2003). Autism. Lancet, 374, 1627-1638.

Volling, B. L., Kolak, A. M., \& Kennedy, D. E. (2009). Empathy and compassionate love in early childhood: Development and family influence. In B. Fehr, S. Sprecher, L. G. Underwood (Eds.), The Science of Compassionate Love: Theory, Research, and Applications (pp. 161-200). doi: $\underline{10.1002 / 9781444303070 . c h 6}$

Walter, S. M., \& Smith, M. J. (2016). Mothering a child with autism. Archives of Psychiatric Nursing, 30(5), 600-601.

doi: 10.1016/j.apnu.2016.01.016 